\title{
Implementasi Fuzzy Inference System Metode Sugeno Pada Aplikasi Penilaian Kinerja Dosen
}

\author{
Fuzzy Inference System Implementation using Sugeno Method in Lecturer Performance \\ Assessment Application \\ Wowon Priatna ${ }^{1}$, Rakhmat Purnomo ${ }^{2}$ \\ ${ }^{1,2}$ Teknik Informatika, Teknik, Universitas Bhayangkara Jakarta \\ E-mail: ${ }^{1}$ wowon.priatna@dsn.ubharajaya, ${ }^{2}$ rakhmat.purnomo@dsn.ubharajaya.ac.id
}

\begin{abstract}
Abstrak
Kinerja dosen dalam perguruan tinggi merupakan bukti nyata yang dihasilkan oleh dosen sebagai prestasi yang ditujukan sesuai perannya. Penilaian kinerja dosen mengacu sistem secara formal dan terstruktur untuk mengukur, menilai, dan mempengaruhi sifat-sifat yang berkatian dengan pekerjaanya.Tujuan dalam penelitan ini adalah untuk menilai kinerja dosen menggunakan Fuzzy Inference System metode Sugeno. Variabel fuzzy yang digunakan adalah pengabungan dari varibel-variabel penelitian sebelumnya diantaranya pengajaran, penelitian $\&$ publikasi, abdimas, penunjang, materi, disiplin dan sikap. ini menghasilkan Aplikasi kinerja dosen yang di dimulai dengan merancang use case diagram, class diagram sebagai bagian dari unified modeling language untuk memodelkan perangkat lunak, selanjutnya merancang interface aplikasi. Berdasarkan penilaian kinerja dosen yang dilakukan oleh aplikasi menggunakan sample 10 dosen, diperoleh skor terendah 60 dan skor tertinggi dengan nilai 100.
\end{abstract}

Kata kunci: Fuzzy Inference System, Metode Sugeno, sistem penilaian kinerja, aplikasi kinerja dosen, Unified Modeling Language.

\begin{abstract}
The performance of lecturers in tertiary institutions is a tangible proof produced by lecturers' achievements in accordance with their roles. Lecturer performance appraisal of a formal and structured system for measuring, assessing, and evaluating traits that are related to their work. The purpose of this research is to assess the performance of lecturers using the Sugeno Fuzzy Inference System. Fuzzy variables that are used are a combination of the variables of previous research, research \& publication, public service, support, material, discipline and attitude. this results in an application improving performance using case diagrams, class diagrams as part of integrated language modeling to model software, then connecting application interfaces. Based on the assessment of the performance of lecturers conducted by the application using a sample of 10 lecturers, the lowest score was 60 and the highest score was 100.
\end{abstract}

Keywords: Fuzzy Inference System, Sugeno Method, performance appraisal system, lecturer performance information system, unified modeling languange

\section{PENDAHULUAN}

Kinerja dosen dalam perguruan tinggi merupakan bukti nyata yang dihasilkan oleh dosen sebagai prestasi yang ditujukan sesuai perannya. Penilaian kinerja dosen mengacu sistem secara formal dan terstruktur untuk mengukur, menilai, dan mempengaruhi sifat-sifat yang berkatian dengan pekerjaanya. Dengan demikian penilaian merupakan hasil kerja personil dan tanggung jawabnya [1].

Afriliana dkk [2] menggunakan fuzzy metode Sugeno untuk mengukur kinerja dosen melalui pengajaran dengan variabel yang digunakan adalah silabus pengajaran, penguasaan materi, metode pengajaran, keterbukaan menerima kritik, kedispilan dan pemenuhan kebutuhan prodi. Penelitian menghasilkan tingkat error yang dihasilkan maka Fuzzy Sugeno tepat 
diimplementasikan untuk pengelompokkan kinerja pengajaran dosen pengampu adalah dengan 32 rules.

Pada penelitian Simanjuntak dan fauzi [3] menilai kinerja dosen menggunakan fuzzy interfeensi system metode sugneno dengan menggunakan 3 variabel diantaranya fisik, materi dan prilaku dosen, system aplikasi dirancang menggunakan bahasa pemograman php dan database Mysql. Sedangkan Pada penelitian Purnomo dkk [4] menilai kinerja dosen dengan membandingkan metode fuzzy interferensi sistem, dengan menggunakan kriteria penilaian dosen berdasarkan pengajaran, penelitian \& publikasi, abdimas dan penunjang. Sedangkan Risky Pratama dan Susanty [5] merancang aplikasi untuk mengukur kinerja dosen menggunakan pemograman php dan metode yang digunakan adalah metode fuzzy Tsukamoto. Variabel yang digunakan untuk mengukur kinerja adalah Fisik, Materi, Perilaku sehingga menhasilkan aplikasi kinerja pegawai yang akurat.

Tujuan penelitan ini adalah untuk memperbaiki penelitain sebelumnya untuk mengukur kinerja dosen dengan mengabungkan beberapa variable tersebut untuk dihitung menggunakan fuzzy interference system metode sugeno. Kemudian hasil yang didapat dari hasil perhitungan fuzzy interference system digunakan untuk merancang aplikasi kinerja dosen menggunakan bahasa pemograman PHP.

\section{METODE PENELITIAN}

Diagram alir yang dalam menjelaskan tahapan dalam penelitian ini dapat dilihat pada gambar 1 .

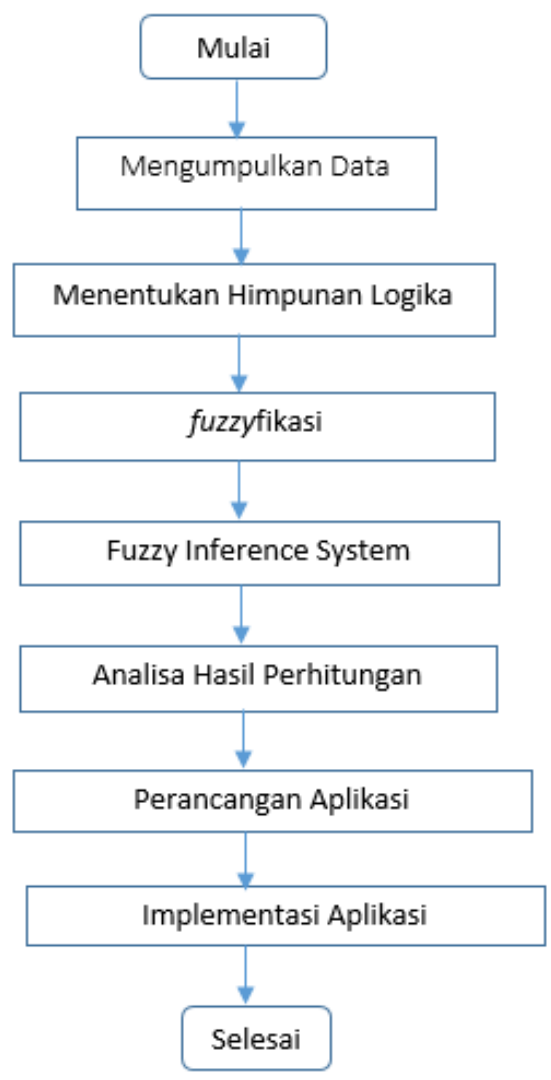

Gambar 1. Tahap Penelitian

Berdasarkan alur proses di atas, penelitian ini membagi metode penelitian menjadi beberapa tahap sebagai berikut: 
2.1 Mengumpulkan data

Tahapan ini pengumpulan data untuk menerapakan metode Fuzzy Inference System dalam menilai kinerja dosen.

\subsection{Analisa penentuan nilai kriteria}

Sebelum melakukan penghitungan dengan system fuzzy inference system, perlu ditentukan terlebih dahulu data rentang nilai kriteria yang akan dijadikan data penilaian kinerja dosen.

\subsection{Menentukan Himpunan Logika Fuzzy}

Logika fuzzy secara umum memiliki tahapan pengerjaan sebagai[6,7]:

1. Menentukan variabel linguistik

2. Membentuk fungsi keanggotaan

3. Membentuk rule base

4. Mengubah data crisp menjadi nilai fuzzy menggunakan fungsi keanggotaan

5. Melakukan evaluasi rule pada rule base

6. Menggabungkan hasil yang didapatkan pada setiap rute

7. Mengubah output data menjadi nilai non fuzzy

Himpunan fuzzy dapat diartikan sebagai suatu kesatuan yang mewakili keadaan tertentu dalam sebuah variabel fuzzy.

\subsection{Fuzzyfikasi Proses}

Proses fuzzyfikasi merupakan perhitungan nilai crisp atau nilai input menjadi derajat keanggotaan. Perhitungan dalam proses fuzzyfikasi berdasarkan batas-batas fungsi keanggotaan[8].

\subsection{Perhitungan dengan Metode FIS}

Sistem Inferensi Fuzzy merupakan suatu kerangka komputasi yang didasarkan pada teori himpunan $f u z z y$, aturan berbentuk $I F-T H E N$, dan penalaran $f u z z y$. Secara garis besar, diagram blok proses sistem inferensi fuzzy terlihat pada Gambar 2.

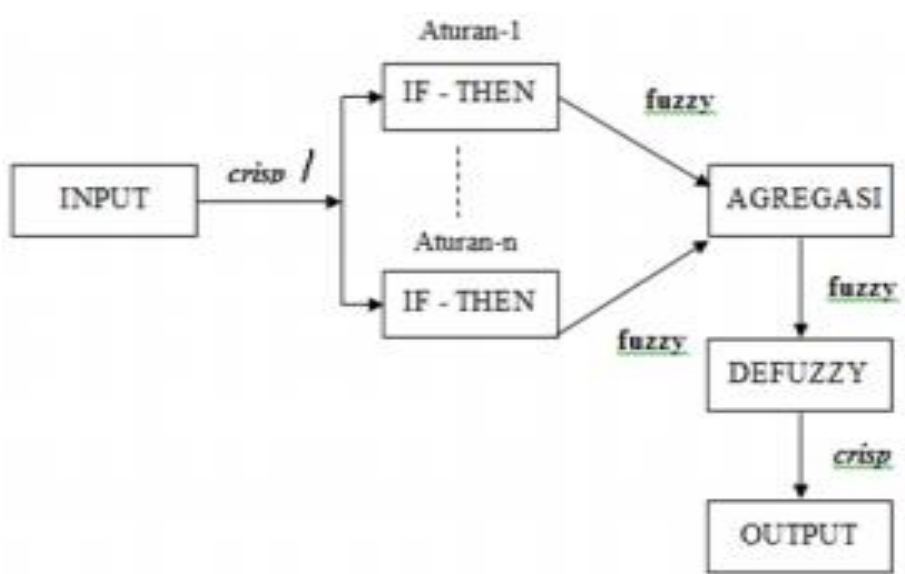

Gambar 2. Blok Sistem Inferensi Fuzzy

Metode sistem inferensi fuzzy sugeno disebut juga metode sistem inferensi fuzzy TSK yang diperkenalkan oleh Takagi, Sugeno dan Kang. Output dari sistem inferensi fuzzy diperlukan 4 tahap $[9,10,11]$ adalah:

1. Tahap Fuzzyfikasi

Fuzzifikasi merupakan proses mentransformasikan data pengamatan kedalam bentuk himpunan fuzzy.

2. Pembentukan aturan dasar data fuzzy 
Aturan dasar fuzzy mendefinisikan hubungan antara fungsi keanggotaan dan bentuk fungsi keanggotaan hasil. Pada metode sugeno output (konsekuen) sistem tidak berupa himpunan fuzzy tetapi berupa konstanta atau persamaan linier. Menurut Cox (1994)[12] metode TSK (Takagi Sugeno Kang) terdiri dari dua jenis, yaitu :

Model fuzzy sugeno orde nol. Secara umum bentuk fuzzy sugeno orde nol adalah :

$\mathrm{IF}(\mathrm{X} 1$ is $\mathrm{A} 1)(\mathrm{X} 2$ is $\mathrm{A} 2)(\mathrm{X} 3$ is $\mathrm{A} 3)(\mathrm{XN}$ is $\mathrm{AN})$ THEN $\mathrm{z}=\mathrm{k}(1)$

Dengan Ai adalah himpunan fuzzy ke -i sebagai anteseden dan $\mathrm{k}$ adalah konstanta tegas sebagai konsekuen. Secara umum bentuk fuzzy sugeno orde satu adalah :

IF (X1 is $\mathrm{A} 1)(\mathrm{X} 2$ is $\mathrm{A} 2)(\mathrm{X} 3$ is $\mathrm{A} 3)(\mathrm{XN}$ is AN) THEN $\mathrm{z}=\mathrm{p} 1 * \mathrm{x} 1+\ldots+\mathrm{pn} * \mathrm{xn}+\mathrm{q}(2)$.

Dengan: Ai adalah himpunan fuzzy ke-i sebagai anteseden, Pi konstanta tegas ke-i dan q konstanta pada konsekuen.

3. Komposisi Aturan (Agregasi)

Apabila sistem terdiri dari beberapa aturan, maka inferensi diperoleh dari kumpulan dan korelasi antar aturan yaitu menghitung hasil.

Dengan:

$$
\sum_{r=1}^{R} \propto_{r} \cdot z_{r}
$$

$\mathrm{R}=$ banyaknya rule

ar $=$ fire strength $\mathrm{ke}-\mathrm{r}$

$\mathrm{zr}=$ output pada anteseden aturan ke-r.

4. Pembentukan aturan dasar data fuzzy

Pada proses ini output berupa bilangan crisp. Defuzifikasi dilakukan dengan cara mencari nilai rata-ratanya adalah :

$$
Z=\frac{\sum_{r}^{R} 1 \propto_{r} \cdot Z_{r}}{\sum_{r}^{R} 1 \propto_{r}}
$$

Metode defuzzifikasi ini dinamakan metode bobot rata-rata terpusat.

\subsection{Analisa Hasil Perhitungan}

Pada tahap ini adalah analisa hasil dari perhitungan system inference fuzzy tentang penilaian kinerja dosen sebagai panduan untuk merancang aplikasi kinerja dosen.

\subsection{Perancangan Aplikasi Kinerja Dosen}

Tahap ini adalah perancangan Aplikasi system pendukung keputusan. Untuk perancangan system menggunakan Use case Diagram, Class diagram yang merupakan bagian dari Unified Modeling language (UML) dan merancang interface dari aplikasi [13][14]. Berikut flow rancangan aplikasi sistem kinerja dosen dapat dilihat pada gambar 3. 

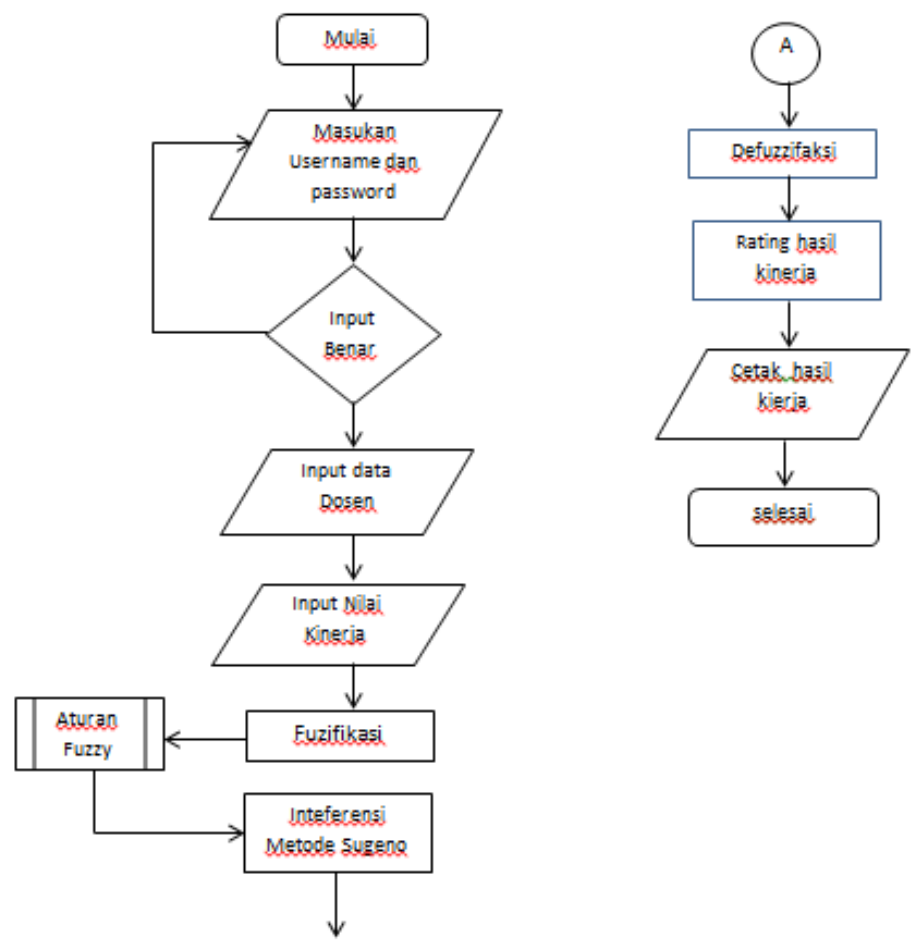

Gambar 3. Alur System Aplikasi Penilaian Kinerja Dosen

\section{HASIL DAN PEMBAHASAN}

Berdasarkan data yang didapat, maka dibuatlah rentang nilai kriteria dari 7 kriteria yaitu Pengajaran (Pj), Penelitian \& publikasi (PP), abdimas (Ad), penunjang (Pg), Materi (M), Disiplin (D) dan Sikap (S). Berdasarkan data yang didapat, maka berikut penjelasan mengenai rentang nilai penilaian kinerja dosen yang ditampilkan pada Tabel 1 .

Tabel 1 Rentang Nilai Kriteria Penelian Kinerja

\begin{tabular}{|l|l|}
\hline \multicolumn{1}{|c|}{ Kriteria } & Range Nilai \\
\hline Pengajaran (Pj) & $0-100$ \\
\hline Penelitian \& publikasi (PP) & $0-100$ \\
\hline Abdimas (Ad) & $0-100$ \\
\hline Penunjang (Pg) & $0-100$ \\
\hline Materi (M) & $0-100$ \\
\hline Disiplin (D) & $0-100$ \\
\hline Sikap (S) & $0-100$ \\
\hline
\end{tabular}

Setelah mendefinisikan data rentang nilai, berikut ini disajikan satu data dosen yang akan dijadikan nilai input pada setiap kriteria. Data salah satu dosen dapat dilihat pada Tabel 2.

Tabel 2. Data Dosen

\begin{tabular}{|c|c|}
\hline Variable Input & Nilai Input \\
\hline $\mathrm{Pj}$ & 77.5 \\
\hline $\mathrm{PP}$ & 83 \\
\hline $\mathrm{Ad}$ & 62 \\
\hline
\end{tabular}




\begin{tabular}{|c|c|}
\hline $\mathrm{Pg}$ & 77 \\
\hline $\mathrm{M}$ & 85 \\
\hline $\mathrm{D}$ & 90 \\
\hline $\mathrm{S}$ & 70 \\
\hline
\end{tabular}

\subsection{Menentukan Logika Fuzzy}

Himpunan fuzzy dalam penelitian ini menggunakan tiga nilai liguistik adalah kurangt, cukup, baik. Pembentukan himpunan fuzzy ini disesuaikan dengan data input kinerja dosen. Data himpunan fuzzy dan nilai linguistiknya data dilihat pada Tabel 3.

Tabel 3. Himpunan Fuzzy

\begin{tabular}{|c|c|}
\hline Variable Input & Nilai Linguistik \\
\hline \multirow[t]{3}{*}{ Pengajaran } & Kurang \\
\hline & Cukup \\
\hline & Baik \\
\hline \multirow[t]{3}{*}{ Penelitian \& Publikasi } & Kurang \\
\hline & Cukup \\
\hline & Baik \\
\hline \multirow[t]{3}{*}{ Abdimas } & Kurang \\
\hline & Cukup \\
\hline & Baik \\
\hline \multirow[t]{3}{*}{ Penunjang } & Kurang \\
\hline & Cukup \\
\hline & Baik \\
\hline \multirow[t]{3}{*}{ Materi } & Kurang \\
\hline & Cukup \\
\hline & Baik \\
\hline \multirow[t]{3}{*}{ Disiplin } & Kurang \\
\hline & Cukup \\
\hline & Baik \\
\hline \multirow[t]{3}{*}{ Sikap } & Kurang \\
\hline & Cukup \\
\hline & Baik \\
\hline
\end{tabular}

\subsection{Fuzzyfikasi Proses}

Berikut ini adalah fungsi keanggotaan himpunan fuzzy dengan 3 kriteria input:

1. Himpunan fuzzy $\mathrm{Pj}$ 


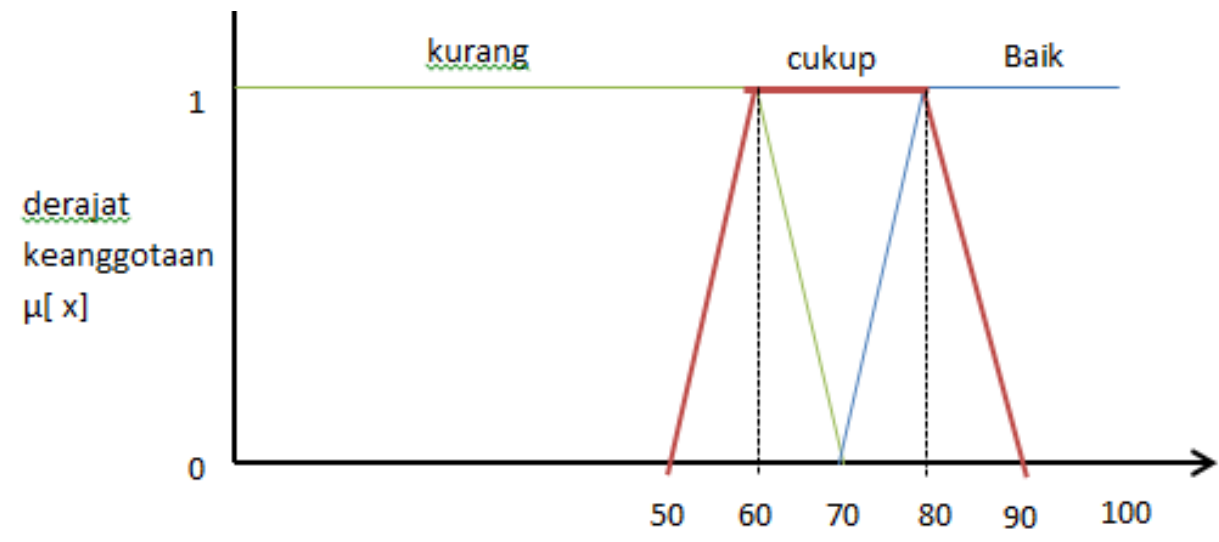

Gambar 4. Kurva fungsi keanggotaan himpunan fuzzy variable pj

Fungsi derajat keanggotaan dari variabel pengajaran seperti yang ditunjukkan pada Gambar 4 didefinisikan dibawah ini:

Fungsi keanggotan variable input pengajaran:

$$
\begin{aligned}
& \propto_{\text {kurang }[x]}=\left\{\begin{array}{c}
1 ; x \leq 50 \\
\frac{60-x}{60-50} ; 50 \leq x \leq 60 \\
0 ; x \geq 70
\end{array}\right. \\
& \propto_{\text {cukup }[x]}=\left\{\begin{array}{c}
0 ; x \leq 0 \\
\frac{x-50}{60-50} ; 50 \leq x \geq 60 \\
1 ; 60 \leq x \leq 80 \\
0 ; \quad x \geq 80
\end{array}\right. \\
& \propto_{\text {baik }[x]}=\left\{\begin{array}{c}
0 ; x \leq 70 \\
\frac{x-70}{80-70} ; 70 \leq x \leq 80 \\
1 ; x \geq 80
\end{array}\right.
\end{aligned}
$$

2. Himpunan fuzzy PP

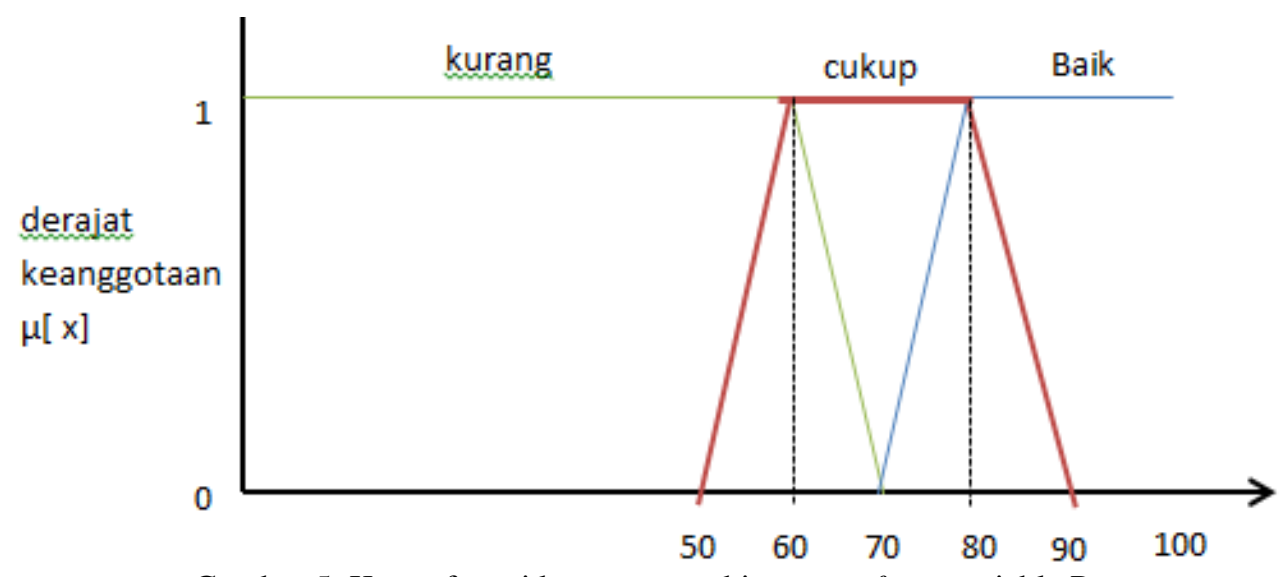

Gambar 5. Kurva fungsi keanggotaan himpunan fuzzy variable Pp 
Fungsi derajat keanggotaan dari variabel penelitian dan publikasi seperti yang ditunjukkan pada Gambar 5, didefinisikan dibawah ini:

Fungsi keanggotan variable input penelitian dan publikasi:

$\propto_{\text {kurang }[x]}=\left\{\begin{array}{c}1 ; x \leq 50 \\ \frac{60-x}{60-50} ; 50 \leq x \leq 60 \\ 0 ; x \geq 70\end{array}\right.$

$\propto_{\text {cukup }[x]}=\left\{\begin{array}{c}0 ; x \leq 0 \\ \frac{x-50}{60-50} ; 50 \leq x \geq 60 \\ 1 ; 60 \leq x 80 \\ 0 ; \quad x \geq 80\end{array}\right.$

$\propto_{\text {baik }[x]}=\left\{\begin{array}{c}0 ; x \leq 70 \\ \frac{x-70 ;}{80-70} ; 0 \leq x \leq 80 \\ 1 ; x \geq 80\end{array}\right.$

3. Himpunan fuzzy Ad

Representasi kurva fungsi keanggotaan himpunan fuzzy input abdimas ditampilkan pada Gambar 6.

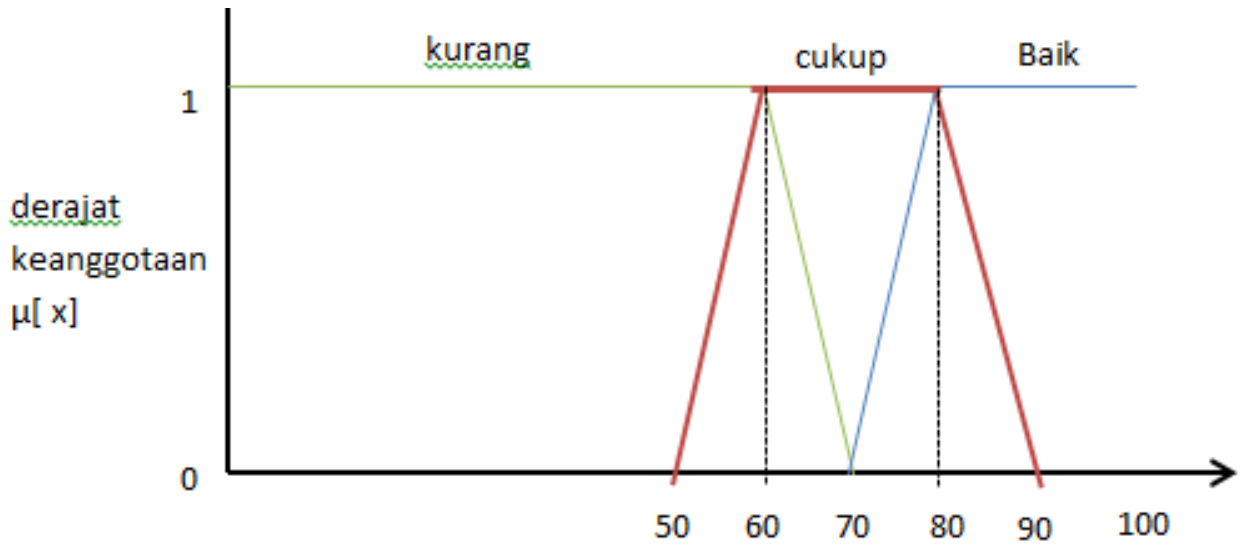

Gambar 6. Kurva fungsi keanggotaan himpunan fuzzy variable Ad

Fungsi keanggotan variable input abdimas:

$$
\begin{aligned}
& \propto_{\text {kurang }[x]}=\left\{\begin{array}{c}
1 ; x \leq 50 \\
\frac{60-x}{60-50} ; 50 \leq x \leq 60 \\
0 ; x \geq 70
\end{array}\right. \\
& \propto_{\text {cukup }[x]}=\left\{\begin{array}{c}
0 ; x \leq 0 \\
\frac{x-50}{60-50} ; 50 \leq x \geq 60 \\
1 ; 60 \leq x 80 \\
0 ; \quad x \geq 80
\end{array}\right.
\end{aligned}
$$




$$
\propto_{\text {baik }[x]}=\left\{\begin{array}{c}
0 ; x \leq 70 \\
\frac{x-70}{80-70} ; 70 \leq x \leq 80 \\
1 ; x \geq 80
\end{array}\right.
$$

\section{Himpunan Fuzzy Input Pg}

Representasi kurva fungsi keanggotaan himpunan fuzzy input penunjang ditampilkan pada Gambar 7.

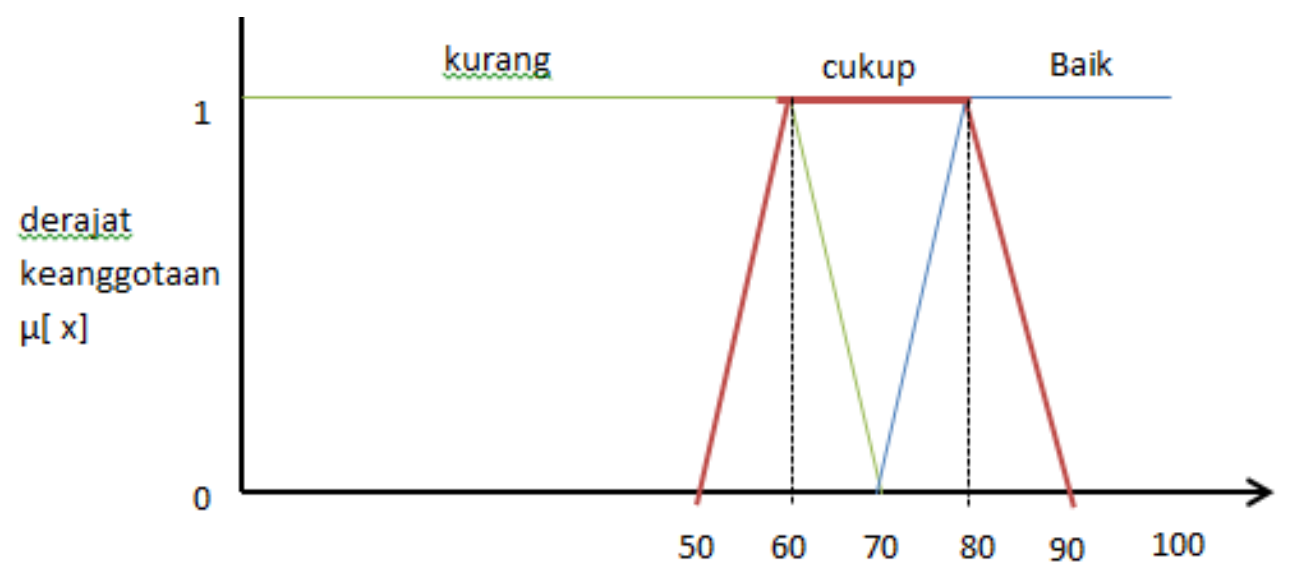

Gambar 7. Kurva fungsi keanggotaan himpunan fuzzy variable pg

Fungsi keanggotan variable input penunjang:

$$
\begin{aligned}
& \propto_{\text {kurang }[x]}=\left\{\begin{array}{c}
1 ; x \leq 50 \\
\frac{60-x}{60-50} ; 50 \leq x \leq 60 \\
0 ; x \geq 70
\end{array}\right. \\
& \propto_{\text {cukup }[x]}=\left\{\begin{array}{c}
0 ; x \leq 0 \\
\frac{x-50}{60-50} ; 50 \leq x \geq 60 \\
1 ; 60 \leq x \leq 80 \\
0 ; \quad x \geq 80
\end{array}\right. \\
& \propto_{\text {baik }[x]}=\left\{\begin{array}{c}
0 ; x \leq 70 \\
\frac{x-70}{80-70} ; 70 \leq x \leq 80 \\
1 ; x \geq 80
\end{array}\right.
\end{aligned}
$$

\section{Himpunan Fuzzy Input M}

Representasi kurva fungsi keanggotaan himpunan fuzzy input materi ditampilkan pada Gambar 8. 


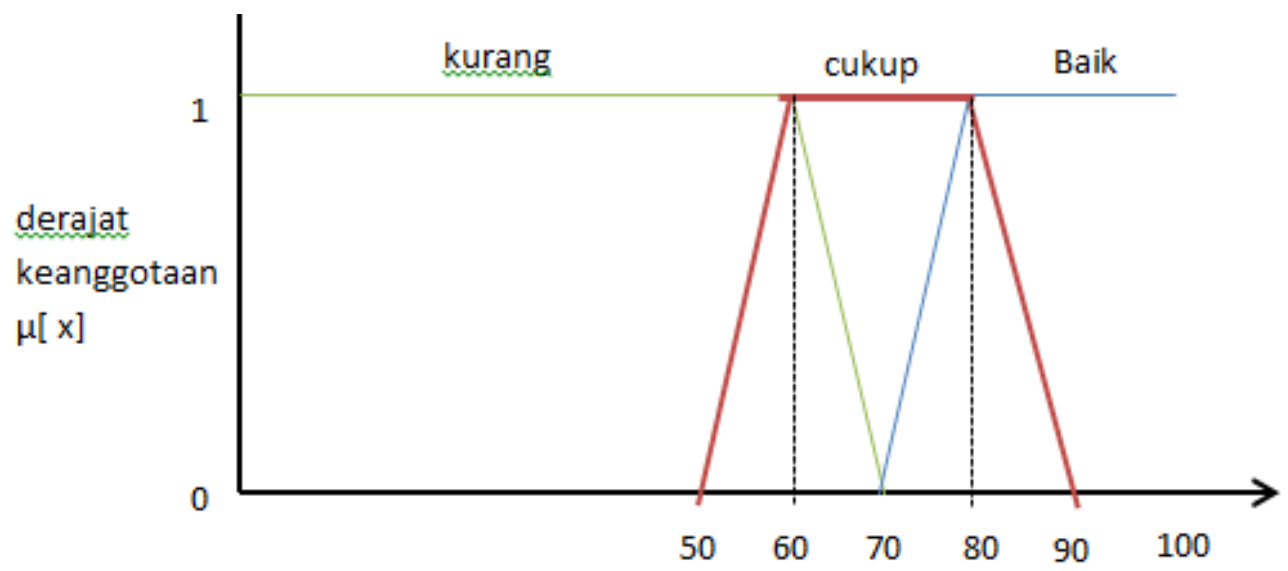

Gambar 8. Kurva fungsi keanggotaan himpunan fuzzy variable M

Fungsi keanggotan variable input materi:

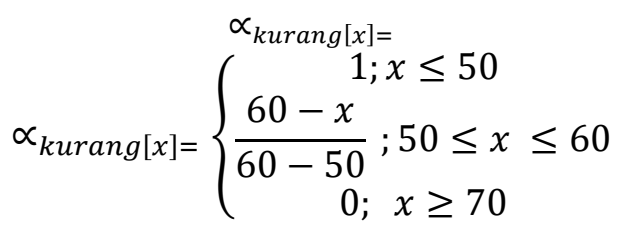

$$
\begin{aligned}
& \propto_{\text {cukup }[x]}=\left\{\begin{array}{c}
0 ; x \leq 0 \\
\frac{x-50}{60-50} ; 50 \leq x \geq 60 \\
1 ; 60 \leq x \leq 80 \\
0 ; \quad x \geq 80
\end{array}\right. \\
& \alpha_{\text {baik }[x]}=\left\{\begin{array}{c}
0 ; x \leq 70 \\
\frac{x-70}{80-70} ; 70 \leq x \leq 80 \\
1 ; x \geq 80
\end{array}\right.
\end{aligned}
$$

\section{Himpunan Fuzzy Input D}

Representasi kurva fungsi keanggotaan himpunan fuzzy input disiplin ditampilkan pada Gambar 9.

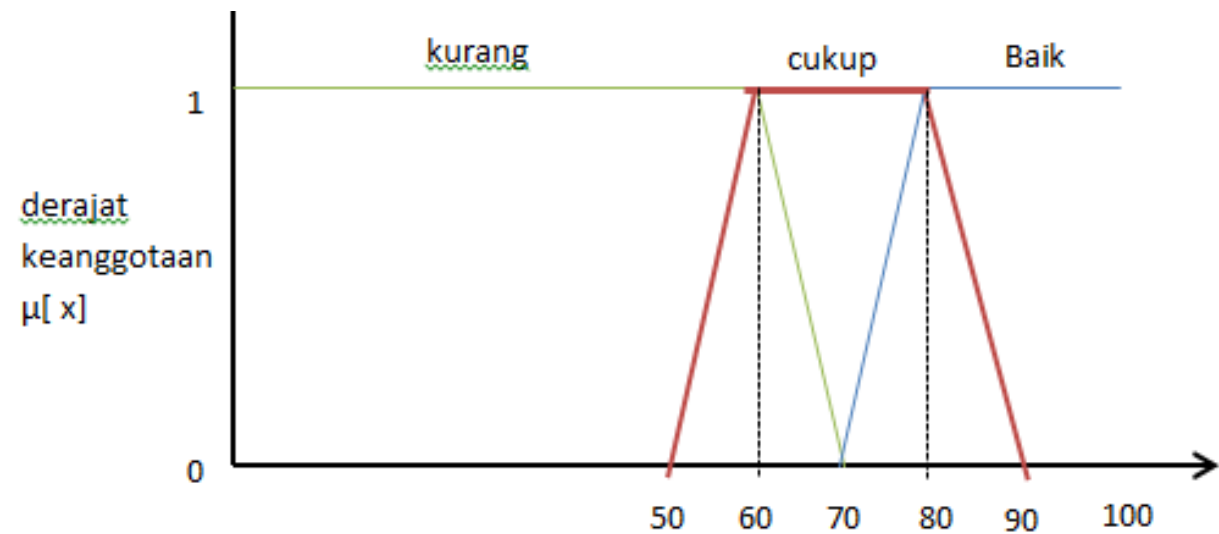

Gambar 9. Kurva fungsi keanggotaan himpunan fuzzy variable D 
Fungsi keanggotan variable input disiplin:

$$
\begin{aligned}
& \propto_{\text {kurang }[x]}=\left\{\begin{array}{c}
1 ; x \leq 50 \\
\frac{60-x}{60-50} ; 50 \leq x \leq 60 \\
0 ; x \geq 70
\end{array}\right. \\
& \propto_{\text {cukup }[x]}=\left\{\begin{array}{c}
0 ; x \leq 0 \\
\frac{x-50}{60-50} ; 50 \leq x \geq 60 \\
1 ; 60 \leq x \leq 80 \\
0 ; \quad x \geq 80
\end{array}\right. \\
& \propto_{\text {baik }[x]}=\left\{\begin{array}{c}
0 ; x \leq 70 \\
\frac{x-70}{80-70} ; 70 \leq x \leq 80 \\
1 ; x \geq 80
\end{array}\right.
\end{aligned}
$$

7. Himpunan Fuzzy Input S

Representasi kurva fungsi keanggotaan himpunan fuzzy input materi ditampilkan pada Gambar 10.

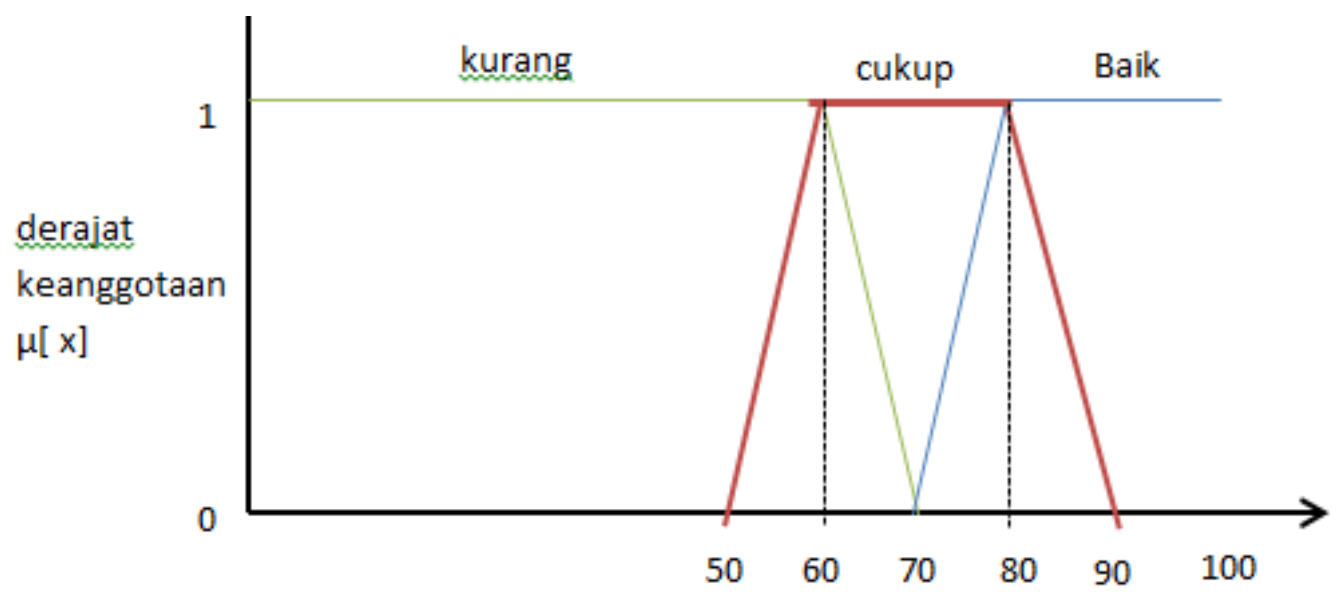

Gambar 10. Kurva fungsi keanggotaan himpunan fuzzy variable $\mathrm{S}$

Fungsi keanggotan variable input sikap:

$$
\begin{aligned}
& \propto_{\text {kurang }[x]}=\left\{\begin{array}{c}
1 ; x \leq 50 \\
\frac{60-x}{60-50} ; 50 \leq x \leq 60 \\
0 ; x \geq 70
\end{array}\right. \\
& \propto_{\text {cukup }[x]}=\left\{\begin{array}{c}
0 ; x \leq 0 \\
\frac{x-50}{60-50} ; 50 \leq x \geq 60 \\
1 ; 60 \leq x \leq 80 \\
0 ; \quad x \geq 80
\end{array}\right.
\end{aligned}
$$




\subsection{Menentukan Logika Fuzzy}

$$
\propto_{\text {baik }[x]}=\left\{\begin{array}{c}
0 ; x \leq 70 \\
\frac{x-70}{80-70} ; 70 \leq x \leq 80 \\
1 ; x \geq 80
\end{array}\right.
$$

Dalam system inferensi fuzzy di tentukan basis rule terlebih dahulu. basis aturan atau rule base jumlah seluruhnya terdapat 114 aturan, tetapi disini hanya 10 rule base yang disajikan pada Tabel 4.

Tabel 4. Rule Base Fuzzy

\begin{tabular}{|c|c|c|c|c|c|c|c|c|}
\hline No & Pj & PP & Ad & pg & M & D & S & Keputusan \\
\hline 1 & kurang & kurang & kurang & kurang & kurang & kurang & kurang & Kurang \\
\hline 2 & kurang & kurang & kurang & kurang & kurang & kurang & kurang & kurang \\
\hline 3 & kurang & kurang & cukup & cukup & kurang & cukup & cukup & cukup \\
\hline 4 & cukup & cukup & cukup & cukup & cukup & cukup & cukup & cukup \\
\hline 5 & cukup & baik & cukup & cukup & baik & baik & kurang & baik \\
\hline 6 & cukup & baik & cukup & cukup & cukup & kurang & kurang & cukup \\
\hline 7 & baik & baik & baik & baik & cukup & kurang & cukup & baik \\
\hline 8 & baik & baik & baik & baik & baik & baik & baik & baik \\
\hline 9 & cukup & kurang & kurang & baik & baik & baik & baik & baik \\
\hline 10 & cukup & kurang & baik & baik & kurang & kurang & baik & cukup \\
\hline
\end{tabular}

Dari Tabel 4 digunakan untuk memproses perhitungan rule Base Fuzzy menggunakan rumus persaman (2-3). Hasil perhitungan ditunjukan pada tabel 5.

Tabel 5.Hasil Perhitungan Rule Base Fuzzy

\begin{tabular}{|c|c|c|c|c|c|c|c|c|c|c|}
\hline No & $\mathbf{P j}$ & $\mathbf{P P}$ & $\mathbf{A d}$ & $\mathbf{P g}$ & $\mathbf{M}$ & $\mathbf{D}$ & $\mathbf{S}$ & $\begin{array}{c}\boldsymbol{\lambda} \text { - } \\
\text { predikat }\end{array}$ & $\mathbf{z}$ & $\boldsymbol{\lambda}$-predikat $* \mathbf{z}$ \\
\hline 1 & 0 & 0 & 0 & 0 & 0 & 0 & 0 & 0 & 60 & 0 \\
\hline 2 & 0 & 0 & 0 & 0 & 0 & 0 & 1 & 0 & 62.86 & 0 \\
\hline 3 & 0 & 0 & 1 & 1 & 0 & 1 & 1 & 0 & 71.43 & 0 \\
\hline 4 & 1 & 1 & 1 & 1 & 1 & 1 & 1 & 1 & 80 & 80 \\
\hline 5 & 1 & 0.1 & 1 & 1 & 0.2 & 0.3 & 1 & 0.1 & 85.71 & 8.571 \\
\hline 6 & 1 & 1 & 1 & 1 & 1 & 0 & 0 & 0 & 74.29 & 0 \\
\hline 7 & 0.75 & 1 & 0 & 0.77 & 1 & 0 & 1 & 0 & 88.57 & 0 \\
\hline 8 & 0.75 & 1 & 0 & 0.77 & 0.72 & 0.3 & 0 & 0 & 100 & 0 \\
\hline 9 & 1 & 0 & 0 & 0.77 & 0.72 & 0.3 & 0 & 0 & 85.71 & 0 \\
\hline 10 & 1 & 0 & 0 & 0.77 & 0 & 0 & 0 & 0 & 80 & 0 \\
\hline & & & & & & & & 1.1 & $\sum \alpha-p^{*} \mathrm{z}$ & 88.571 \\
\hline
\end{tabular}

Setelah didapat output dari setiap aturan ( $\left.\propto \_r . z \_r\right)$, maka dilakukan defuzzifikasi dengan menghitung rata-rata bobot terpusat dari masing-masing aturan berdasarkan persamaan (2-4). Sehingga didapatkan nilai z:

$$
=\frac{(1 * 80)+(0.1 * 85.71)}{1+0.1}
$$




$$
z=97.43
$$

\subsection{Analisis Hasil Perhitungan}

Setelah dilakukan analisis fuzzy inference systems diperoleh hasil skor kinerja. Tahap selanjutnya adalah melakukan penggolongan predikat kinerja berdasarkan hasil skor kinerja. Adapun predikat kinerja yang digunakan dalam penelitian ini dapat dilihat pada Tabel 6 .

Tabel 6. Penggolongan Predikat Kinerja

\begin{tabular}{|l|l|}
\hline \multicolumn{1}{|c|}{ Rentang Skor } & \multicolumn{1}{c|}{ Predikat Kinerja } \\
\hline $0 \leq$ Skor $\geq 60$ & kurang \\
\hline $61 \leq$ Skor $\geq 80$ & cukup \\
\hline $81<$ Skor $\leq 100$ & Baik \\
\hline
\end{tabular}

Dari Tabel 6 diperoleh kesimpulan bahwa predikat kinerja salah satu dosen dengan nilai 97.43 termasuk ke dalam kategori baik.

\subsection{Merancang Aplikasi Penilian Kinerja}

Aplikasi ini menggunakan perhitungan Fuzzy Logic berdasrkan metode Sistem Inferensi Fuzzy Sugeno. Diharapkan dengan adanya metode penalaran tersebut, sebagai usulan lembaga perguruan tinggi dalam mempermudah dalam menilai kinerja dosen. Untuk perancangan system di modelkan mengunakan use case dan class diagram yang merupakan diagram $U M L$ (Unified modeling Language) yang berfungsi memodelkan user yang berinteraksi dengan sistem. Diagram Use Case dan Class diagram untuk aplikasi penilaian kinerja dosen ditunjukan pada gambar 11 dan gambar 12.

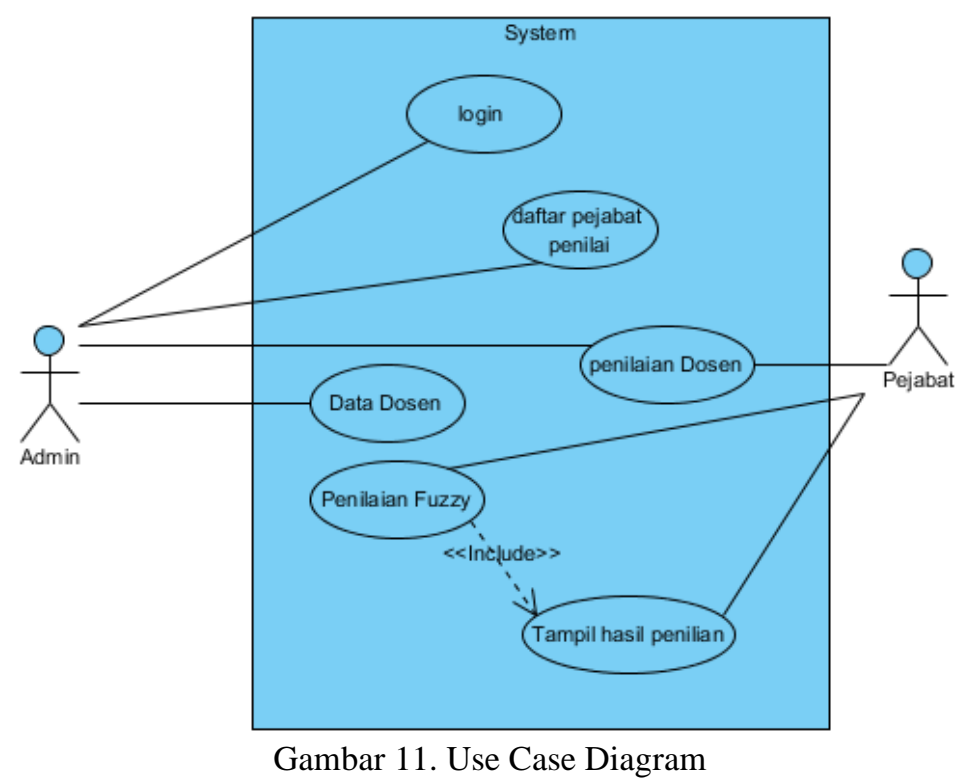

Use case diagram pada gambar 11 menjelaskan fitur-fitur atau menu yang ada di aplikasi sistem penilaian kinerja terdapat dua aktor pejabat dan admin sebagai pengguna sistem sedangkan class diagram pada gambar 12 menjelaskan relasi antar class untuk membangun sistem. 


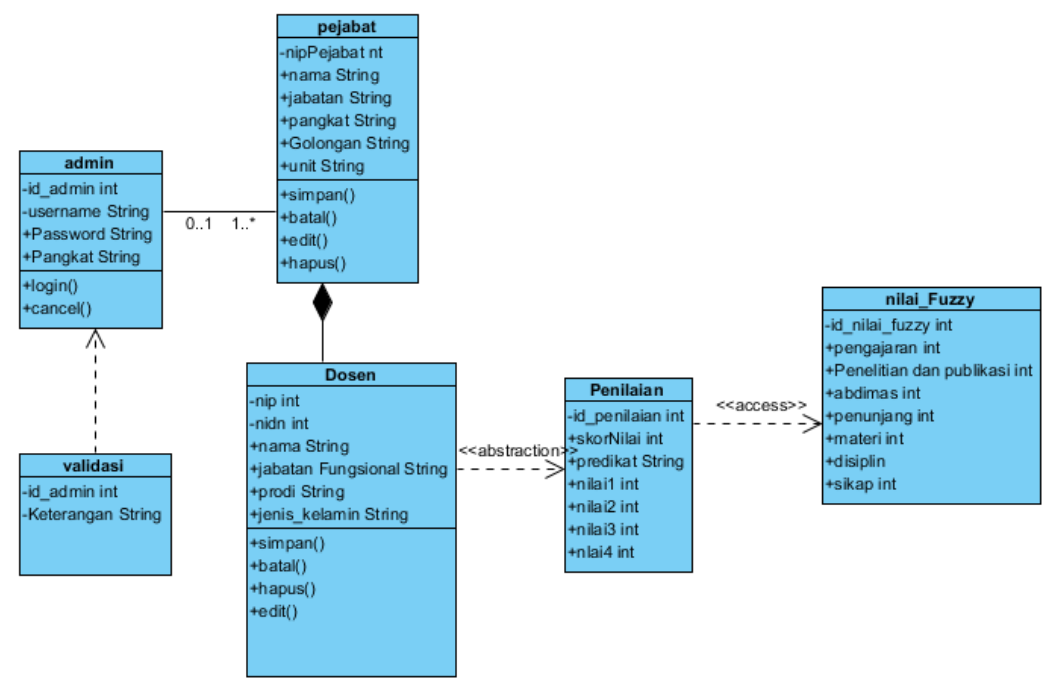

Gambar 12. Class Diagram

\subsection{Hasil Perancangan Aplikasi}

Berikut adalah sebagian interface dari dari tampilan aplikasi penilaian kinerja dosen.

\section{Halaman Data Dosen}

Pada halaman data dosen berfungsi untuk input, edit, delete data dosen yang dilakukan oleh admin. Tampilan halaman data dosen dapat dilihat pada gambar 13.

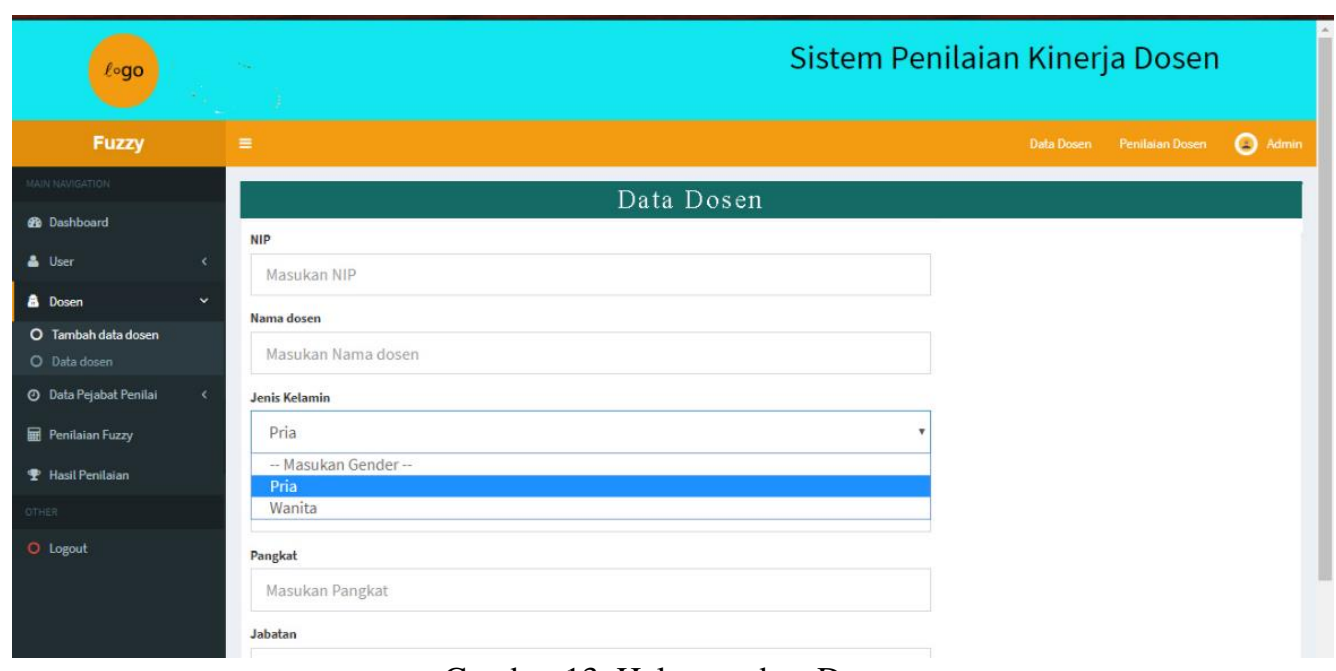

Gambar 13. Halaman data Dosen

\section{Halaman Lembar penilaian}

Halaman penilian berfungsi untuk melakukan input laporan dosen. Halaman ini sebagai data untuk sebagai input laporan dari dosen mengenai pengajaran, penelitian \& publikasi, abdimas dan penunjang. Tampilan lembar penilaian dapat dilihat pada gambar 14 . 


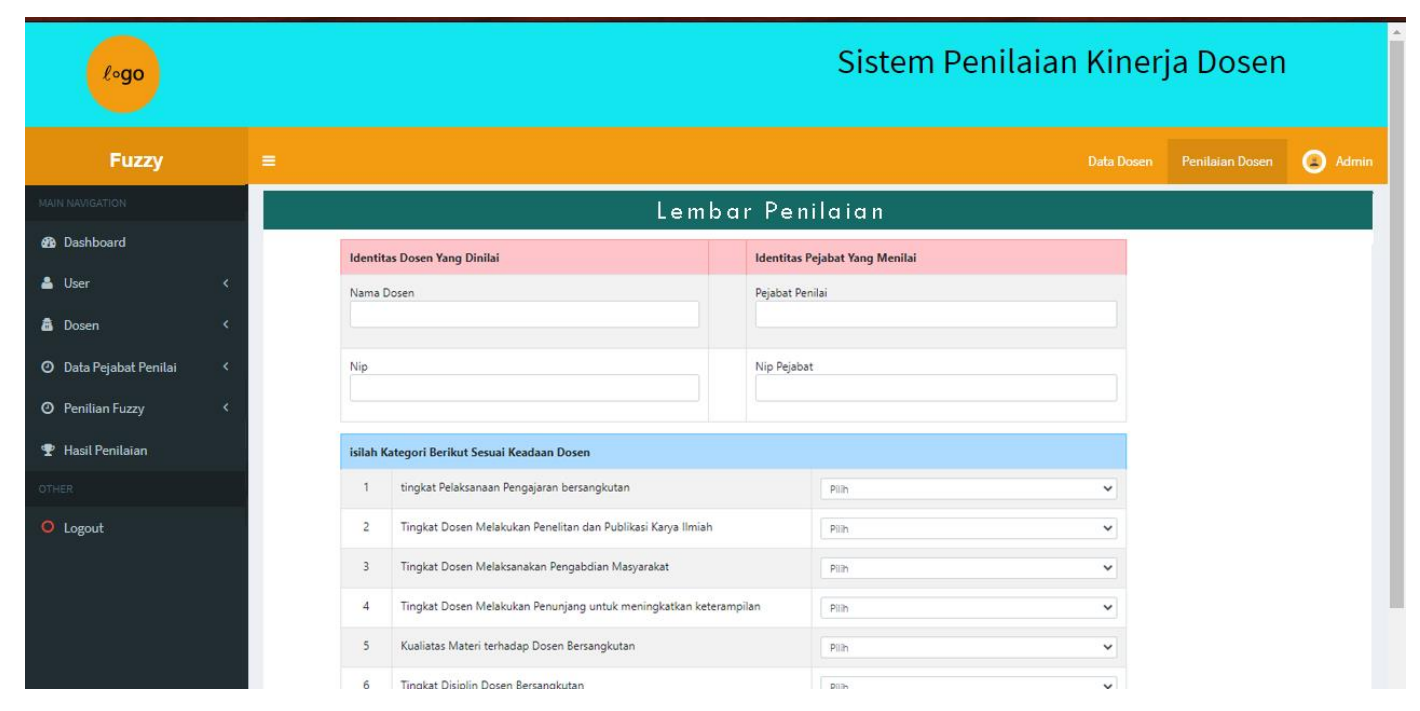

Gambar 14. Halaman Hitung fuzzy

\section{Halaman dosen yang sudah dinilai}

Pada halaman ini dapat dilihat dosen yang sudah dan belum dinilai. Halaman ini diakses oleh pejabat yang berwenang. Tampilan halaman untuk melihat dosen sudah dinilai dapat dilihat pada gambar 15 .

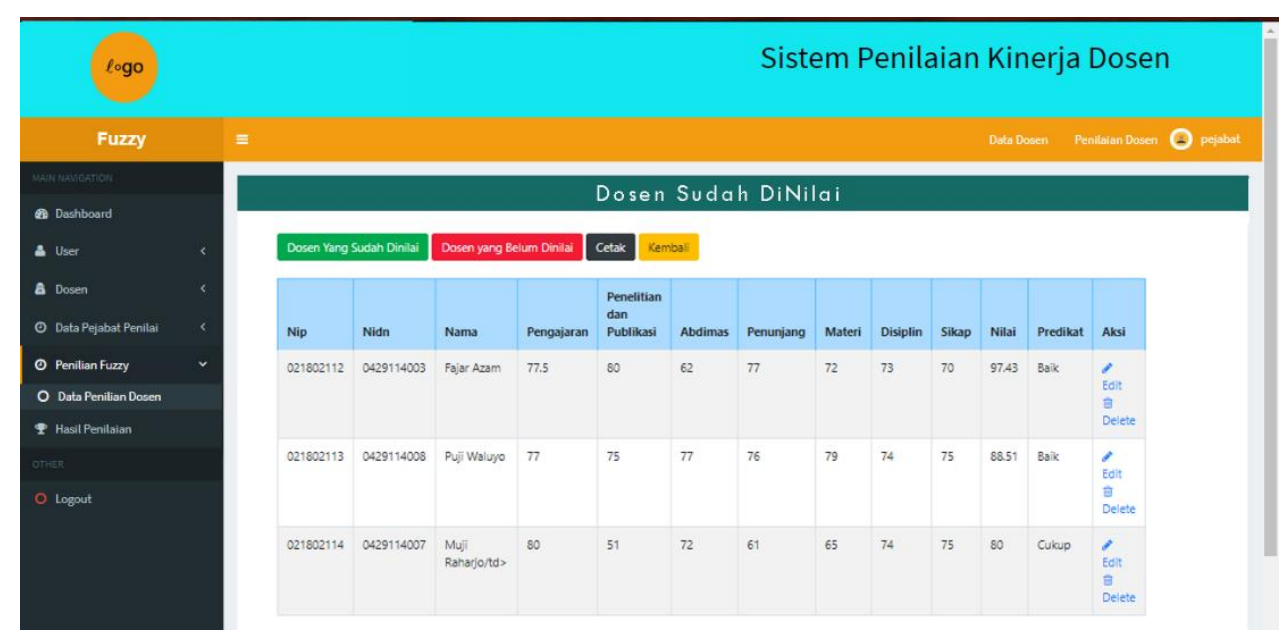

Gambar 15. Halaman dosen sudah dinilai

\section{Halaman Hasil Penilaian}

Pada halaman ini adalah hasil penilian yang telah dilakukan oleh pejabat berwenang untuk menilai dosen. Halaman hasil penilaian dapat dilihat pada gambar 16. 


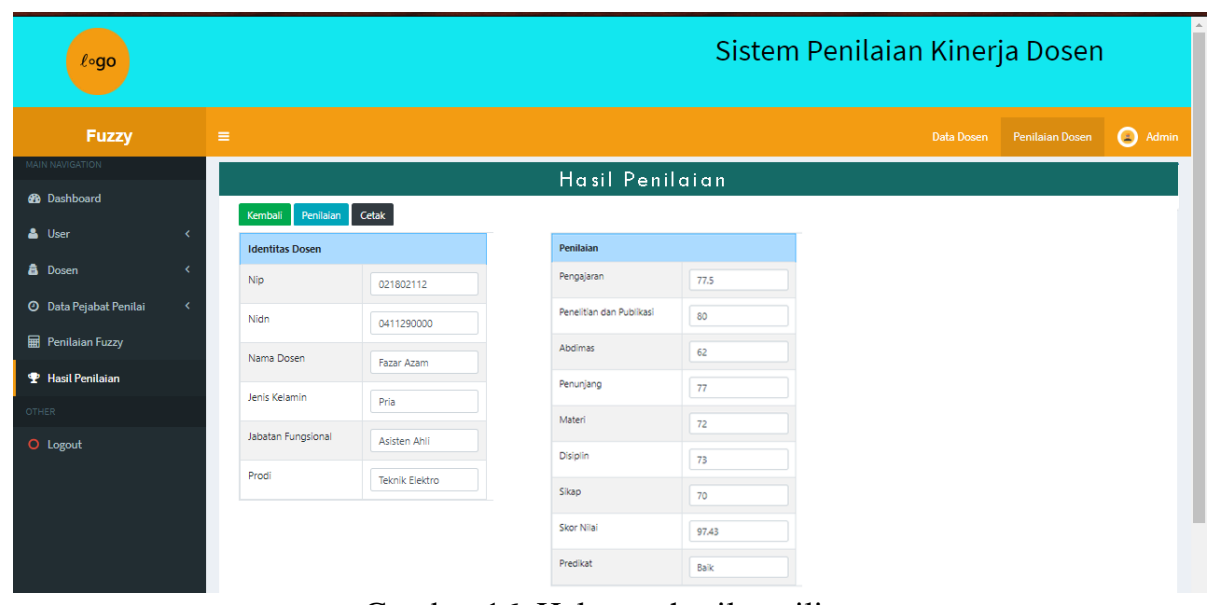

Gambar 16. Halaman hasil penilian

Berdasarkan penilaian kinerja dosen yang dilakukan oleh aplikasi, diperoleh skor kinerja untuk 10 orang dosen yang tersaji pada Tabel 7.

Tabel 7. Hasil Kinerja Dosen Berdasarkan Aplikasi

\begin{tabular}{|c|c|c|c|c|c|c|c|c|c|}
\hline Nama Dosen & PJ & PP & AD & PG & M & D & S & $\begin{array}{c}\text { Penilaian } \\
\text { Aplikasi }\end{array}$ & $\begin{array}{c}\text { Sebutan } \\
\text { Fuzzy }\end{array}$ \\
\hline Fajar & 77.5 & 80 & 62 & 77 & 72 & 73 & 70 & 97.43 & Baik \\
\hline Muji & 80 & 51 & 72 & 61 & 65 & 74 & 75 & 80 & Cukup \\
\hline Puji & 77 & 75 & 77 & 76 & 79 & 74 & 75 & 88.51 & Baik \\
\hline Ima & 78 & 51 & 77 & 76 & 75 & 74 & 57 & 80 & Cukup \\
\hline Hadi & 81 & 83 & 90 & 95 & 93 & 92 & 88 & 100 & Baik \\
\hline Sigit & 55 & 51 & 52 & 53 & 53 & 54 & 57 & 69.71 & cukup \\
\hline Elkin & 81 & 77 & 75 & 83 & 81 & 78 & 82 & 100 & Baik \\
\hline Tiara & 82 & 83 & 84 & 85 & 90 & 91 & 81 & 100 & Baik \\
\hline Retno & 77 & 72 & 63 & 62 & 65 & 51 & 72 & 80 & Cukup \\
\hline Tri & 49 & 45 & 50 & 45 & 49 & 48 & 51 & 60 & kurang \\
\hline
\end{tabular}

Hasil penilaian menunjukkan bahwa dosen yang memiliki nilai terendah adalah skor nilai 60 dan dosen yang memperoleh skor nilai tertinggi dengan skor nilai 100, Ini berarti kinerja dosen secara keseluruhan mendapat predikat Baik.

\section{KESIMPULAN DAN SARAN}

Sudah dibangun sebuah aplikasi untuk menilai kinerja dosen menggunakan fuzzy interference system berdasarkan pengajaran, penelitian \& publikasi, abdimas, penunjang, materi, disiplin dan sikap dengan mendapatkan 114 rule base fuzzy. Pengimplementasian aplikasi ini diterapkan pada tahap kalkulasi penilaian kinerja dosen dimana nilai dari tiap-tiap variabel yang telah diinputkan dilakukan fuzzifikasi terlebih dahulu. Selanjutnya dilakukan inferensi terhadap aturan yang dipakai dan diakhiri dengan tahap defuzzifikasi yang berupa penghitungan skor menggunakan metode berbobot rata- rata. Dengan metode fuzzy sugeno ini diperoleh skor kinerja tertinggi yaitu 100 dan skor kinerja terendah adalah sebesar 60 . 


\section{DAFTAR PUSTAKA}

[1] Adi Suwasono, Damar. (2016). Sistem Evaluasi Kinerja Dosen. Matangglumpangdua: Universitas Almuslim.

[2] Afriliana, I., Haqiqi Sulasmoro, A., \& Sofyan, A. (2019). Implementasi Fuzzy Sugeno Untuk Kinerja Pengajaran Dosen. Smart Comp: Jurnalnya Orang Pintar Komputer, 8(2), 74-77.

[3] Simanjuntak, M., \& Fauzi, A. (2017). Penerapan Fuzzy Mamdani Pada Penilaian Kinerja Dosen (Studi Kasus STMIK Kaputama Binjai), 2(2), 143-149

[4] Purnomo, R., Priatna, W., \& Fathurrozi, A. (2019). Perbandingan Logika Fuzzy Dan Analytic Hierarchy Process Untuk Menilai Kinerja Dosen. XIV(1), 48-59.

[5] Pratama, Andyka Risky, W. S. (2010). Aplikasi kinerja dosen berbasis fuzzy untuk mengukur tingkat kinerja mengajar dosen pada fakultas ilmu komputer bandar lampung. 110 .

[6] Utomo, MCC \& Mahmudy, WF 2015, 'Penerapan FIS-Tsukamoto untuk menentukan potensi seseorang mengalamivsudden cardiac death', Seminar Nasional Sistem Informasi Indonesia (SESINDO), Institut Teknologi Sepuluh Nopember (ITS), Surabaya, 2-3 November, pp. 239-244.

[7] Hadi, H. N., Mahmudy, W. F., \& Brawijaya, U. (2015). Penilaian Prestasi Kinerja Pegawai Menggunakan Fuzzy. 2(1), 41-48.

[8] Restuputri, B. A., Mahmudy, W. F. \& Cholissodin, I. 2015. Optimasi fungsi keanggotaan fuzzy Tsukamoto dua tahap menggunakan algoritma genetika pada pemilihan calon penerima beasiswa dan BBP-PPA (studi kasus: PTIIK Universitas Brawijaya Malang). DORO: Repository Jurnal Mahasiswa PTIIK Universitas Brawijaya.

[9] Jokar, M., Ghannadpour, S. F., \& Makui, A. (2018). Fuzzy analytical network process logic for performance measurement system of e-learning centers of Universities. 11(3), 261-280.

[10] Mohammad Syarif Irfan, Much Aziz Muslim, F. Y. A. (2017). Implementasi Fuzzy Inference System Metode Sugeno Pada. 6(2), 178-188.

[11] Kusumadewi, S, Purnomo, H. 2010. Aplikasi Logika Fuzzy untuk Pendukung Keputusan. Yogyakarta: Graha Ilmu.

[12] Cox, Earl, 1994, “The Fuzzy System handbook". Massachusetts: Academic Press - Inc

[13] Priatna, W., \& Nugroho, A. (2019). Sistem Pendukung Keputusan Untuk Penentuan Dosen Favorit Menggunakan Simple Additive Weighting ( SAW ). (4), 181-190

[14] Priatna, W., \& Suryadi. (2019). Perancangan Sistem Pendukung Keputusan Untuk Pemilihan Lokasi Dalam Perluasan Usaha Kafe menggunakan Analytical Hierarchy Process. Jurnal RESTI (Rekayasa Sistem Dan Teknologi Informasi), 3(3), 511-517. 